\title{
Factors associated with active aging in Finland, Poland, and Spain
}

\author{
Jaime Perales, ${ }^{1}$ Steven Martin, ${ }^{2}$ Jose Luis Ayuso-Mateos, ${ }^{3}$ Somnath Chatterji, ${ }^{4}$ \\ Noe Garin, ${ }^{1}$ Seppo Koskinen, ${ }^{5}$ Matilde Leonardi, ${ }^{6}$ Marta Miret, ${ }^{7,8}$ Victoria Moneta, ${ }^{1}$ \\ Beatriz Olaya, ${ }^{7}$ Beata Tobiasz-Adamczyk ${ }^{9}$ and Josep Maria Haro ${ }^{1,7}$ \\ ${ }^{1}$ Parc Sanitari Sant foan de Déu, Sant Boi de Llobregat, Barcelona, Spain \\ ${ }^{2}$ Department of Public Health $\mathcal{E}$ Primary Care, Cambridge Institute of Public Health, University of Cambridge, Cambridge, UK \\ ${ }^{3}$ Department of Psychiatry, Universidad Autónoma de Madrid, Centro de Investigación Biomédica en Red de Salud Mental (CIBERSAM), Instituto de \\ Investigación Sanitaria Princesa (IP), Hospital Universitario la Princesa, Madrid, Spain \\ ${ }^{4}$ Department of Health Statistics and Information Systems, World Health Organization, Geneva, Switzerland \\ ${ }^{5}$ National Institute for Health and Welfare, Helsinki, Finland \\ ${ }^{6}$ Department of Neurology, Public Health and Disability, Italian National Neurological Institute "Carlo Besta" Foundation IRCCS (Istituto di ricovero e cura \\ a carattere scientifico), Milan, Italy \\ 7 Instituto de Salud Carlos III, Centro de Investigación Biomédica en Red de Salud Mental, CIBERSAM, Madrid, Spain \\ ${ }^{8}$ Department of Psychiatry, Universidad Autónoma de Madrid, Hospital Universitario de La Princesa, Instituto de Investigación Sanitaria Princesa (IP), \\ Madrid, Spain \\ ${ }^{9}$ Chair of Epidemiology and Preventive Medicine, Department of Medical Sociology, fagiellonian University Medical College, Krakow, Poland
}

Background: Continuous population aging has raised international policy interest in promoting active aging (AA). AA theoretical models have been defined from a biomedical or a psychosocial perspective. These models may be expanded including components suggested by lay individuals. This paper aims to study the correlates of AA in three European countries, namely, Spain, Poland, and Finland using four different definitions of AA.

Methods: The EU COURAGE in Europe project was a cross-sectional general adult population survey conducted in a representative sample of the noninstitutionalized population of Finland, Poland, and Spain. Participants $(10,800)$ lived in the community. This analysis focuses on individuals aged 50 years old and over $(7,987)$. Four definitions (two biomedical, one psychosocial, and a complete definition including biomedical, psychosocial, and external variables) of AA were analyzed.

Results: Differences in AA were found for country, age, education, and occupation. Finland scored consistently the highest in AA followed by Spain and Poland. Younger age was associated with higher AA. Higher education and occupation was associated with AA. Being married or cohabiting was associated with better AA compared to being widowed or separated in most definitions. Gender and urbanicity were not associated with AA, with few exceptions. Men scored higher in AA only in Spain, whereas there was no gender association in the other two countries. Being widowed was only associated with lower AA in Poland and not being married was associated with lower AA in Poland and Finland but not Spain.

Conclusions: Associations with education, marital status, and occupation suggest that these factors are the most important components of AA. These association patterns, however, seem to vary across the three countries. Actions to promote AA in these countries may be addressed at reducing inequalities in occupation and education or directly tackling the components of AA lacking in each country.

Key words: active aging, old age, successful aging, aging well, geriatrics

\section{Introduction}

The continuing growth of older age groups in the European Union (EU) has raised international

Correspondence should be addressed to: Josep Maria Haro, Parc Sanitari Sant Joan de Déu, Sant Boi de Llobregat, Barcelona, Spain. Phone: +3493600 26 85. Email: jmharo@pssjd.org. Received 26 Nov 2013; revision requested 1 Feb 2014; revised version received 23 Feb 2014; accepted 27 Feb 2014. First published online 15 April 2014 policy interest in promoting active aging (AA) (Walker, 2009; European Union, 2012). AA has been defined as "the process of optimizing opportunities for health, participation, and security in order to enhance quality of life as people age" (World Health Organization, 2013a). This and other concepts such as successful (Rowe and Kahn, 1997), productive (Kerschner and Pegues, 1998), and positive aging (Bowling, 1993) 
refer to an optimistic view of aging. Contrary to more traditional paradigms of human aging, these terms include gains as well as losses positing possible improvement in future human health despite increasing longevity (Fries, 2012). These terms have been used interchangeably by several authors (Lupien and Wan, 2004; Depp and Jeste, 2006). Despite having specific semantic specifications (Fernández-Ballesteros et al., 2013), in the following text, AA will be used to encompass all these concepts.

Models of AA are controversial. No agreement exists across disciplines about definitions. Biomedical, psychosocial, and lay perspectives have been used to conceptualize AA (Bowling and Dieppe, 2005). Biomedical theories define AA largely in terms of the optimization of healthy life expectancy, i.e. minimizing deterioration in physical and mental functioning and reducing disability. Psychosocial models emphasize life satisfaction, social participation and functioning, and psychological resources, including personal growth. Lay perspectives of older people have been used to add domains not usually captured by theoretical models (Cosco et al., 2013). In addition to physical, psychological, and social domains (Fernández-Ballesteros, 2008), these perspectives include external variables such as financial and environmental security (Cosco et al., 2013). There is also debate about appropriate cut-off points in measures used (Depp and Jeste, 2006). Moreover, what some studies consider to be constituents of AA (e.g. income) are regarded as factors influencing AA in others (Strawbridge et al., 1996; Bowling and Iliffe, 2006; Fernández-Ballesteros et al., 2013).

The comparison of the percentage of people who are actively aging across studies is of limited use given the wide variety of definitions and measurement approaches. The proportion of active agers varies greatly, from $0.4 \%$ to 95\% (Depp and Jeste, 2006). This is due to different conceptualizations, operationalizations, and methodologies. Also, by splitting individuals into active and nonactive agers, it is assumed that people cannot actively age with, for example, conditions such as HIV or schizophrenia (Ibrahim et al., 2010; Malaspina et al., 2011). However, it seems more appropriate to treat AA as a continuum. Analyzing how much someone ages actively provides richer information than merely indicating if someone is actively aging.

The current study aims to study the distribution and correlates of AA in three different European countries, namely, Spain, Poland, and Finland. The research addresses the following questions: Does the distribution of active agers vary among countries? If so, does this depend on the definition of AA used? What factors are associated with AA? Do these factors vary by country?

\section{Methods}

\section{Design}

COURAGE in Europe is an observational, cross-sectional three year study of general noninstitutionalized adult population (18 years or older) reached through household interviews. The sample is representative of three European countries (Finland, Poland, and Spain). These countries were selected to give a broad representation across different European regions, representing, respectively, the north, the east, and the south of Europe, taking into consideration their population and health characteristics.

\section{Sample and procedure}

A stratified, multistage cluster sample design was used to obtain nationally representative samples. A probability proportion to size design was used to select clusters. Within each cluster, an enumeration of existing households was done to obtain an accurate measurement of size. Interviews were conducted face-to-face by Computer-Assisted Personal Interviewing (CAPI) at respondent's homes. All the interviewers participated in a training course for the administration of the survey. Quality control procedures were implemented during fieldwork (Ustun et al., 2005). The instruments were translated from English into Finnish, Polish, and Spanish following the World Health Organization (WHO) translation guidelines for assessment instruments, which included a forward translation, a targeted back-translation, review by a bilingual expert group, and a detailed translation report (World Health Organization, 2013b). The surveys were conducted between 2011 and 2012. Ethical approvals from the relevant ethics committees (Parc Sanitari Sant Joan de Déu, Barcelona, Spain; Hospital la Princesa, Madrid, Spain; National Institute for Health and Welfare, Helsinki, Finland, and Jagiellonian University Medical College, Krakow, Poland) and written informed consent from each participant were obtained. The sample size was composed of 10,800 individuals: 1,976 from Finland, 4,071 from Poland, and 4,753 from Spain. The individual response rate was $69.9 \%$ in Spain, $66.5 \%$ in Poland, and $53.4 \%$ in Finland. Only those aged 50 years old and above who did not need a proxy respondent were included in this study. Therefore, the final sample size was 7,987: 1,452 from Finland, 2,910 from Poland, and 3,625 from Spain. 


\section{Measures}

Participants were asked to provide sociodemographic information (age, gender, education level, marital status, occupation, household income, and urbanicity). Categories for highest level of education completed were "never been to school," "less than primary school," "primary school completed," "secondary school completed," "high school completed," "college/pre-university/university completed," and "post-graduate degree completed." Information on marital status was collected as follows: never married, currently married, cohabiting, separated/divorced, and widowed. Occupation was defined using ISCO 08 categories (European Commission, 2009). These categories are divided into nine main groups: managers, professionals, technicians and associate professionals, clerical support workers, service and sales workers, skilled agricultural, forestry and fishery workers, craft and related trades workers, plant and machine operators, and assemblers and elementary occupations.

Chronic medical conditions were assessed by asking whether the individuals had been diagnosed by a doctor with chronic lung disease, asthma, hypertension, arthritis, stroke, angina, and diabetes. In addition, an algorithm of symptoms was used to detect nondiagnosed cases of arthritis, stroke, angina, chronic lung disease, and asthma. Disability was assessed with the 12-item interviewer administered version of the World Health Organization Disability assessment Schedule version II (WHO-DAS II) (World Health Organization, 2012). Participants were asked to report the level of difficulty they had in doing various activities such as dressing or concentrating during the previous 30 days using a five-point scale (none $=1$, mild $=2$, moderate $=3$, severe $=4$, and extreme/cannot do $=5$ ). The total score ranges from 0 to 100 with higher scores indicating greater disability. Cognitive functioning was assessed through five performance tests measuring three different domains: learning and short-term memory (delayed and immediate recall of words), working memory (digit span forward and backward), and verbal fluency (animal naming task). A composite of these five scores was calculated ( $\mathrm{He}$ et al., 2012). Psychiatric morbidity was assessed using an adapted version of the Depression module of the WHO Composite International Diagnostic Interview (CIDI) (Kessler and Ustün, 2004). This is a fully structured lay-administered interview that generates diagnoses according to the ICD-10 DCR definition and criteria (World Health Organization, 1992). Physical activity was measured using the Global Physical Activity Questionnaire (Armstrong and Bull, 2006) and collects information on physical activity participation in three settings as well as sedentary behavior, comprising 16 questions. The domains are activity at work; travel to and from places; and recreational activities. Tobacco consumption was assessed by asking if the participants were daily smokers, nondaily smoker, former smokers, or never smokers. Alcohol consumption was assessed by asking if the participants were lifetime abstainers, and if not, the pattern of alcohol consumption in the previous week based on which they were classified as being occasional drinkers, nonheavy drinkers, infrequent heavy drinkers or heavy drinkers. Those who did not consume alcohol in the previous 30 days or in the previous seven days were categorized as occasional drinkers. Participants who consumed alcohol in the previous 30 days and in the previous seven days were labeled as nonheavy drinkers. Participants who consumed alcohol -one to two days per week, with five or more standard drinks in previous seven days for men and four or more for women were categorized as infrequent heavy drinkers. Participants who did consume alcohol three or more days per week with five or more standard drinks in last seven days for men and four or more for women were categorized as frequent heavy drinkers. Social participation was measured using 11 fivepoint Likert scale questions on how often in the last 12 months the person had participated in activities such as attending public meetings or meeting community leaders. Social contacts were measured using 10 five-point Likert scale questions on how often in the last 12 months the person had contact with other people such as their partner, children, or neighbors. Social support was measured using the Oslo social support scale (Bøen et al., 2012). This scale consists of three items: "How many people are you so close to that you can count on them if you have great personal problems? [none (1), 1-2 (2), 35 (3), 5+ (4)]," "How much interest and concern do people show in what you do? [a lot (5), some (4), uncertain (3), little (2), none (1)]," and "How easy is it to get practical help from neighbors if you should need it? [very easy (5), easy (4), possible (3), difficult (2), very difficult (1)]." Control and coping were measured with one item each on how unable the person is to control important things in life and to cope with things they have to do. Selfrated quality of life was measured with a single fivepoint Likert scale question ranging from very good to very bad. Environmental safety was measured through two items asking: "In general, how safe from crime and violence do you feel at your home?" and 'How safe do you feel when walking down your street (neighborhood) alone after dark?" ranging from completely safe to not safe at all in a five-point Likert scale. 
Table 1. Construction of models of AA

\begin{tabular}{|c|c|c|c|}
\hline $\begin{array}{l}\text { ROWE \& KAHN'S } \\
\text { BIOMEDICAL MODEL } \\
\text { RANGE }(0-5)\end{array}$ & $\begin{array}{l}\text { BIOMEDICAL MODEL } \\
\text { RANGE }(0-7)\end{array}$ & $\begin{array}{l}\text { PSYCHOSOCIAL MODEL } \\
\text { RANGE }(0-6)\end{array}$ & $\begin{array}{l}\text { COMPLETE MODEL } \\
\text { RANGE }(0-15)\end{array}$ \\
\hline $\begin{array}{l}\text {-No chronic medical } \\
\text { conditions } \\
\text {-Below the median in } \\
\text { WHODAS-II } \\
\text { - Equal or above the } \\
\text { median in the cognition } \\
\text { composite standardized } \\
\text { by education } \\
\text {-No depression in the last } \\
12 \text { months } \\
\text {-Engaged in three or more } \\
\text { different social } \\
\text { participation activities at } \\
\text { least once a month }\end{array}$ & $\begin{array}{l}\text {-No chronic medical } \\
\text { conditions } \\
\text { - Below the median in } \\
\text { WHODAS-II } \\
\text { - Equal or above the } \\
\text { median in the cognition } \\
\text { composite standardized } \\
\text { by education } \\
\text {-No depression in the last } \\
12 \text { months } \\
\text {-Current nonsmoker } \\
\text {-Occasional drinker or } \\
\text { lifetime abstainer } \\
\text {-Moderate or high physical } \\
\text { activity }\end{array}$ & $\begin{array}{l}\text {-Engaged in three or more } \\
\text { different social } \\
\text { participation activities at } \\
\text { least once a month } \\
\text {-Three or more social } \\
\text { contacts with at least one } \\
\text { month of frequency } \\
\text {-Score of } 12-14 \text { (strong } \\
\text { support) in the Oslo } \\
\text { social support scale } \\
\text {-Good or very good } \\
\text { self-rated quality of life } \\
\text {-Never or almost never } \\
\text { unable to control } \\
\text { important things in life } \\
\text {-Never or almost never } \\
\text { unable to cope with } \\
\text { things they have to do }\end{array}$ & $\begin{array}{l}\text {-No chronic medical } \\
\text { conditions } \\
\text { - Below the median in } \\
\text { WHODAS-II } \\
\text { - Equal or above the } \\
\text { median in the cognition } \\
\text { composite standardized } \\
\text { by education } \\
\text {-No depression in the last } \\
\text { 12 months } \\
\text {-Current nonsmoker } \\
\text {-Occasional drinker or } \\
\text { lifetime abstainer } \\
\text {-Moderate or high physical } \\
\text { activity } \\
\text {-Engaged in three or more } \\
\text { different social } \\
\text { participation activities at } \\
\text { least once a month } \\
\text {-Three or more social } \\
\text { contacts with at least one } \\
\text { month of frequency } \\
\text {-Score of } 12-14 \text { (strong } \\
\text { support) in the Oslo } \\
\text { social support scale } \\
\text {-Good or very good } \\
\text { self-rated quality of life } \\
\text {-Never or almost never } \\
\text { unable to control } \\
\text { important things in life } \\
\text {-Never or almost never } \\
\text { unable to cope with } \\
\text { things they have to do } \\
\text {-Household income equal } \\
\text { or above the median in } \\
\text { each of the countries } \\
\text {-Very or completely safe } \\
\text { both in both items: at } \\
\text { home and on the street } \\
\text { (environmental safety) }\end{array}$ \\
\hline
\end{tabular}

The indicators used for the construction of the different models of AA were selected on the basis of previous literature (Bowling and Dieppe, 2005; Depp and Jeste, 2006) (Table 1). The models were Rowe and Kahn's biomedical definition of AA (Rowe and Kahn, 1997) (avoidance of disease and disability, maintenance of high physical and cognitive function, and sustained engagement in social and productive activities), two models including strictly biomedical or psychosocial indicators and a complete model including all indicators. For the comparison of factors associated to AA by country, only the complete definition of AA was used since it represents the multidimensional nature of AA (Cosco et al., 2013). The definitions of AA were operationalized as the sum of the different indicators. The higher the score, the more actively people aged.

\section{Statistical methods}

Univariate analyses included means and their standard deviations. Linear regression analysis [beta, 95\% confidence intervals (95\% CIs)] was used for bivariate and multivariate analyses. The level for statistical significance for all analyses 
was set at 0.05. Imputations for missing data were not used. Those participants who were not able to respond to the survey due to cognitive problems were not included in the main analysis. We conducted a sensitivity analysis using Rowe and Kahn's definition of AA also including those individuals. In this analysis, we created a dichotomous-dependent variable (actively ageing vs. not actively aging). Active agers were those who fulfilled all the criteria for Rowe and Kahn's definition of AA. Those with cognitive problems were assumed to be aging in a nonactive way. We then compared associations with sociodemographic variables (country, age, gender, educational status, occupation, marital status, and urbanicity) of the sample including those with and without cognitive problems using logistic regression.

All data were weighted to account for sampling design in each country. Poststratification corrections were made to the weights to adjust for the population distribution obtained from the national census from each country and for nonresponse. In order to make valid comparisons across countries, age and sex were standardized on the basis of the European Standard Population (World Health Organization, 1990). All analyses were performed using the Stata version 11.0 using the survey package (StataCorp, 2009).

\section{Results}

\section{Characteristics of participants and description of variables included in the models of AA}

Tables 2 and 3 summarize the demographic characteristics of the participants and the description of the variables selected for the inclusion in the different models of AA. Poland had the lowest percentage of people free from disability (33\% vs. $53 \%$ and $58 \%$ in Spain and Finland, respectively), moderate to high physical activity $(76 \%$ vs. $80 \%$ and $83 \%)$, social contacts ( $96 \%$ vs. $99 \%$ and $98 \%$ ), self-reported quality of life ( $57 \%$ vs. $64 \%$ and $78 \%$ ), control ( $51 \%$ vs. $71 \%$ and $87 \%$ ), coping ( $52 \%$ vs. $68 \%$ and $89 \%$ ), and environmental safety ( $43 \%$ vs. $59 \%$ and $74 \%$ ). Spain had the lowest percentage of people without depression (88\% vs. $95 \%$ and $96 \%$ in Poland and Finland) and the highest percentage of people with no chronic conditions ( $34 \%$ vs. $28 \%$ and $26 \%$ ), strong social support ( $57 \%$ vs. $24 \%$ and $24 \%$ ). Finland had the lowest percentage of life abstainers and occasional drinkers (57\% vs. 73.2 and $62 \%$ in Poland and Spain) and highest percentage of good cognition ( $75 \%$ vs. $36 \%$ and $53 \%$ ), current nonsmokers $(72 \%$ vs. $66 \%$ and $68 \%$ ), physical activity, social participation, self-reported quality of life, control, coping, and environmental safety. The prevalence of AA operationalized as those fulfilling all criteria in the different models has been reported in the supplementary material for the interested reader (SM1).

\section{Correlates of AA}

Tables 4 and 5 show the bivariate and multivariate associations of the different definitions of AA with socio-demographic variables. Looking at Table 4, there was a consistent gradient regarding country across all definitions of AA where Poland had the lowest score, followed by Spain and Finland. Men had significantly higher scores than women in all definitions except for the biomedical one, in which women had a higher score. Age was inversely associated with all AA definitions. There was an education gradient where those with lower studies scored lower than those with higher studies. A similar gradient was found regarding occupation. Widows had lower scores of AA than those married or cohabiting across all definitions. The same applies to those who were currently divorced except for Rowe and Kahn's definition in which there was no significance. Those who had never been married had lower scores than those married or cohabiting in the psychosocial and complete definitions. Finally, people living in urban areas scored higher in AA in the biomedical model.

Multivariate analysis confirms all these results except for few exceptions. Mainly men had no longer higher scores than women in the psychosocial and complete definitions. The education gradient was not so evident. There was no longer an occupation gradient in the biomedical definition and only having less than incomplete primary education is significantly associated with lower AA compared to having completed college or university.

\section{Correlates of AA by country}

Table 6 shows the multivariate associations of the complete definition of AA with sociodemographic variables by country. The comparison of factors associated with the other three definitions of AA by country can be found in the supplementary material (SM2). Men had higher scores than women in Spain. Women had scored higher than men in Poland. There were no associations with gender in Finland. Age was still inversely associated with AA in the three countries. There were still education and occupation gradients in all countries although not all categories reached significance. Widows and divorced/separated had lower scores than those who were married or cohabiting in the three countries. Having never been married was associated with lower AA in both Poland and Finland. Urbanicity 
Table 2. Demographic characteristics of participants in the Spanish, Polish, and Finish samples.

\begin{tabular}{|c|c|c|c|c|c|c|c|c|c|}
\hline \multirow{2}{*}{ Gender: $n(\%)$} & \multicolumn{2}{|c|}{$\begin{array}{l}\text { POLAND } \\
n=2,910\end{array}$} & \multicolumn{2}{|c|}{$\begin{array}{c}\text { SPAIN } \\
n=3,625\end{array}$} & \multicolumn{2}{|c|}{$\begin{array}{c}\text { FINLAND } \\
n=1,452\end{array}$} & \multirow[t]{2}{*}{$\begin{array}{l}\text { SIGNIFICANCE } \\
\text { AMONG } \\
\text { COUNTRIES } \\
\text { p VALUE }\end{array}$} & \multicolumn{2}{|c|}{$\begin{array}{c}\text { COMPLETE } \\
n=7,987\end{array}$} \\
\hline & & & & & & & & & \\
\hline Women & 1,765 & 57.5 & 1,982 & 53.7 & 834 & 54.7 & 0.043 & 4,581 & 55.2 \\
\hline Men & 1,145 & 42.5 & 1,643 & 46.4 & 618 & 45.3 & & 3,406 & 44.8 \\
\hline \multicolumn{10}{|l|}{ Age: $n(\%)$} \\
\hline $50-59$ & 1,050 & 35.1 & 1,206 & 32.2 & 451 & 31.7 & 0.000 & 2,707 & 33.2 \\
\hline $60-69$ & 861 & 30.2 & 1,041 & 28.2 & 495 & 33.9 & & 2,397 & 30.0 \\
\hline $70-79$ & 527 & 18.3 & 999 & 29.4 & 284 & 19.2 & & 1,810 & 23.5 \\
\hline $80+$ & 472 & 16.3 & 379 & 10.3 & 222 & 15.3 & & 1,073 & 13.4 \\
\hline Age: mean (sd) & 65.7 & 11.0 & 66.0 & 10.5 & 66.1 & 10.6 & 0.520 & 65.9 & 10.7 \\
\hline \multicolumn{10}{|c|}{ Highest education level completed: $n(\%)$} \\
\hline $\begin{array}{l}\text { College/university/ } \\
\text { postgraduate }\end{array}$ & 420 & 15.1 & 393 & 10.9 & 407 & 25.2 & 0.000 & 1,220 & 15 \\
\hline High school & 817 & 29.9 & 541 & 14.5 & 503 & 34.8 & & 1,861 & 23.8 \\
\hline Secondary school & 762 & 26.5 & 408 & 11.1 & 284 & 21.2 & & 1,454 & 18.5 \\
\hline Primary school & 792 & 24.9 & 1,075 & 31.3 & 235 & 17.3 & & 2,102 & 26.4 \\
\hline $\begin{array}{l}\text { Never/incomplete } \\
\text { primary school }\end{array}$ & 119 & 3.6 & 1,207 & 32.3 & 20 & 1.4 & & 1,346 & 16.2 \\
\hline \multicolumn{10}{|l|}{ Occupation: $n(\%)^{\mathrm{b}}$} \\
\hline Skill level 1 & 330 & 11.9 & 541 & 16.7 & 145 & 10.6 & 0.000 & 1,016 & 13.8 \\
\hline Skill level 2 & 1,324 & 52.9 & 1,559 & 48.8 & 689 & 50.1 & & 3,572 & 50.5 \\
\hline Skill level 3 & 738 & 30.7 & 680 & 19.9 & 581 & 38.0 & & 1,999 & 27.2 \\
\hline Never worked & 127 & 4.5 & 497 & 14.6 & 19 & 1.3 & & 643 & 8.5 \\
\hline \multicolumn{10}{|l|}{ Marital status: $n(\%)$} \\
\hline Never married & 266 & 7.5 & 310 & 8.5 & 118 & 8.4 & 0.000 & 694 & 8.1 \\
\hline Currently married & 1,611 & 63.8 & 2,189 & 60.7 & 833 & 56.7 & & 4,633 & 61.1 \\
\hline Cohabiting & 39 & 1.7 & 69 & 1.8 & 88 & 6.3 & & 196 & 2.6 \\
\hline Separated/divorced & 229 & 6.2 & 266 & 7.0 & 174 & 12.0 & & 669 & 7.6 \\
\hline Widowed & 765 & 20.8 & 791 & 22.1 & 238 & 16.7 & & 1,794 & 20.6 \\
\hline \multicolumn{10}{|l|}{ Urbanicity: $n(\%)$} \\
\hline Rural & 1,247 & 31.4 & 487 & 16.2 & 340 & 24.0 & 0.077 & 2,074 & 23.1 \\
\hline Urban & 1,663 & 68.7 & 3,138 & 83.9 & 1,112 & 76.0 & & 5,913 & 76.9 \\
\hline
\end{tabular}

${ }^{a}$ Weighted percentage

bISCO 08 categories were categorized into three levels according to their skill level. Skill level 3 corresponds to technicians and associate professionals, professionals, and managers. Skill level 2 corresponds to occupations between plant and machine operators and assemblers and clerical support workers. Skill level 1 corresponds to elementary occupations.

was not associated with the complete definition of AA in any country.

\section{Sensitivity analysis}

The associations between sociodemographic variables and AA using Rowe and Kahn's model were similar in the sample including those who could not participate due to cognitive problems and the sample that included these individuals. This information can be found in the supplementary material (SM3).

\section{Discussion}

This article has examined the distribution of AA and their correlates in three different European countries, including the factors associated with AA and their variation depending upon the definition of AA being operationalized. Significant country differences were found in all the definitions of AA with Poland having the lowest score, followed by Spain and Finland. Age, education, marital status, and occupation are the most important factors associated to AA. The patterns of associations, however, seem to vary across the three countries. After adjusting for other sociodemographic variables, gender (with the exception of the biomedical model in which women are better off than men) and urbanicity were not associated with a propensity to AA.

Finnish participants had better AA than their Spanish counterparts and these than their Polish counterparts. Similar trends have been reported in the SHARE project (Hank, 2011) in which among 
Table 3. Description of the components of AA by country.

\begin{tabular}{|c|c|c|c|c|c|c|c|c|c|}
\hline \multirow{2}{*}{$\begin{array}{l}\text { VARIABLES } \\
\text { WITHIN THE } \\
\text { MODELS } \\
\text { Biomedical variables }\end{array}$} & \multicolumn{2}{|c|}{$\begin{array}{l}\text { POLAND } \\
n=2,910\end{array}$} & \multicolumn{2}{|c|}{$\begin{array}{l}\text { SPAIN } \\
n=3,625\end{array}$} & \multicolumn{2}{|c|}{$\begin{array}{l}\text { FINLAND } \\
n=1,452\end{array}$} & \multirow[t]{2}{*}{$\begin{array}{l}\text { P VALUE FOR } \\
\text { DIFFERENCE } \\
\text { AMONG } \\
\text { COUNTRIES }\end{array}$} & \multicolumn{2}{|c|}{$\begin{array}{l}\text { COMPLETE } \\
n=7,987\end{array}$} \\
\hline & $n$ & $\%$ & $n$ & $\%$ & $n$ & $\%$ & & $n$ & $\%$ \\
\hline Chronic conditions & & & & & & & 0.000 & & \\
\hline None $^{a}$ & 824 & 27.5 & 1,237 & 34.3 & 380 & 26.3 & & 2,441 & 30.4 \\
\hline Disability & & & & & & & 0.000 & & \\
\hline Below the median ${ }^{a}$ & 945 & 32.7 & 1,920 & 53.4 & 851 & 58.4 & & 3,716 & 46.8 \\
\hline $\begin{array}{l}\text { Cognition (by } \\
\text { education) }\end{array}$ & & & & & & & 0.000 & & \\
\hline $\begin{array}{l}\text { Equal or above } \\
\text { median }^{\mathrm{a}}\end{array}$ & 1,042 & 35.8 & 1,814 & 52.7 & 1,007 & 75.2 & & 3,863 & 50.2 \\
\hline $\begin{array}{l}\text { Depression (12 } \\
\text { months) }\end{array}$ & & & & & & & 0.000 & & \\
\hline $\mathrm{No}^{\mathrm{a}}$ & 2,736 & 94.8 & 3,191 & 87.9 & 1,396 & 96.1 & & 7,323 & 91.9 \\
\hline Alcohol consumption & & & & & & & 0.000 & & \\
\hline $\begin{array}{l}\text { Lifetime abstainers/ } \\
\text { occasional }^{\mathrm{a}}\end{array}$ & 2,177 & 73.2 & 2,233 & 61.5 & 819 & 56.8 & & 5,229 & 64.9 \\
\hline $\begin{array}{l}\text { Tobacco } \\
\text { consumption }\end{array}$ & & & & & & & 0.000 & & \\
\hline Current nonsmokers ${ }^{\mathrm{a}}$ & 1,890 & 65.7 & 2,465 & 68.4 & 1,063 & 72.4 & & 5,418 & 68.1 \\
\hline Physical activity & & & & & & & 0.123 & & \\
\hline $\begin{array}{l}\text { Moderate/high } \\
\text { Psychosocial variables }\end{array}$ & 2,167 & 75.7 & 2,889 & 80.2 & 1,221 & 83.3 & & 6,277 & 79.1 \\
\hline $\begin{array}{l}\text { Social participation } \\
\text { activities }\end{array}$ & & & & & & & 0.000 & & \\
\hline Three or more ${ }^{\mathrm{a}}$ & 1,201 & 38.1 & 1,504 & 42.2 & 999 & 67.4 & & 3,704 & 45.3 \\
\hline Social contacts & & & & & & & 0.000 & & \\
\hline Three or more ${ }^{a}$ & 2,804 & 96.3 & 3,587 & 98.9 & 1,416 & 98.0 & & 7,807 & 97.8 \\
\hline Social support & & & & & & & 0.000 & & \\
\hline Strong $^{\mathrm{a}}$ & 672 & 23.6 & 1,955 & 56.5 & 335 & 24.1 & & 2,962 & 38.4 \\
\hline $\begin{array}{l}\text { Self reported quality } \\
\text { of life }\end{array}$ & & & & & & & 0.000 & & \\
\hline Good/very good ${ }^{\mathrm{a}}$ & 1,583 & 56.5 & 2,325 & 64.4 & 1,126 & 77.6 & & 5,034 & 63.9 \\
\hline $\begin{array}{l}\text { Unable to control the } \\
\text { important things in } \\
\text { life }\end{array}$ & & & & & & & 0.000 & & \\
\hline Never/almost never ${ }^{\mathrm{a}}$ & 1,511 & 51.1 & 2,550 & 70.5 & 1,205 & 86.6 & & 5,266 & 66.2 \\
\hline $\begin{array}{l}\text { Unable to cope with } \\
\text { the things to be } \\
\text { done }\end{array}$ & & & & & & & 0.000 & & \\
\hline $\begin{array}{l}\text { Never/almost never } \\
\text { External variables }\end{array}$ & 1,511 & 51.6 & 2,444 & 68.2 & 1,252 & 88.7 & & 5,207 & 65.8 \\
\hline Household Income & & & & & & & 0.965 & & \\
\hline $\begin{array}{l}\text { Equal or above } \\
\text { country median }\end{array}$ & 1,320 & 49.8 & 1,674 & 50.2 & 724 & 49.3 & & 3,718 & 49.9 \\
\hline Environmental safety & & & & & & & 0.000 & & \\
\hline $\begin{array}{l}\text { Very safe/completely } \\
\text { safe }^{\text {a }}\end{array}$ & 1,275 & 43.2 & 2,143 & 58.8 & 1,003 & 73.8 & & 4,421 & 55.7 \\
\hline
\end{tabular}

All variables recoded and dichotomized as $1 / 0,1$ being the criterion for AA.

${ }^{\text {a }}$ Criterion of AA

14 European countries, Poland was the one with less active agers, followed by Spain. Nordic countries such as Denmark and Sweden were the countries with most active agers. The samples in both studies, however, differ regarding age. In the SHARE study, the participants were 65 years and older, whereas in our study the participants were 50 years and older being more than $30 \%$ of participants younger than 60 years old. Therefore, these trends do not seem to depend on age and could be related to the 
Table 4. Simple linear regression showing associations [coefficient, $95 \%$ confidence interval $(95 \% \mathrm{CI})$ ] with correlates on alternate AA models.

\begin{tabular}{|c|c|c|c|c|}
\hline & ROWE \& KAHN’S & BIOMEDICAL & PSYCHOSOCIAL & COMPLETE \\
\hline & RANGE $(0-5)$ & RANGE (0-7) & RANGE $(0-6)$ & RANGE (0-15) \\
\hline & $\begin{array}{l}\text { MEAN }(3.0), 95 \% \text { CI } \\
(2.9 ; 3.1)^{\mathrm{a}}\end{array}$ & $\begin{array}{l}\text { MEAN }(4.7), 95 \% \text { CI } \\
(4.6 ; 4.7)^{\mathrm{a}}\end{array}$ & $\begin{array}{l}\text { MEAN }(3.8), 95 \% C I \\
(3.6 ; 3.9)^{\mathrm{a}}\end{array}$ & $\begin{array}{l}\text { MEAN }(9.5), 95 \% \text { CI } \\
(9.3 ; 9.7)^{\mathrm{a}}\end{array}$ \\
\hline & $\begin{array}{l}\text { COEFFICIENT } \\
(95 \% \mathrm{CI})\end{array}$ & $\begin{array}{l}\text { COEFFICIENT } \\
(95 \% \mathrm{CI})\end{array}$ & $\begin{array}{l}\text { COEFFICIENT } \\
(95 \% \mathrm{CI})\end{array}$ & $\begin{array}{l}\text { COEFFICIENT } \\
(95 \% \mathrm{CI})\end{array}$ \\
\hline \multicolumn{5}{|l|}{ Country } \\
\hline Poland (ref) & - & - & - & - \\
\hline Spain & $0.42(0.28 ; 0.56)^{*}$ & $0.34(0.20 ; 0.48)^{*}$ & $0.86(0.69 ; 1.03)^{*}$ & $1.35(1.07 ; 1.63)^{*}$ \\
\hline Finland & $0.97(0.87 ; 1.08)^{*}$ & $0.66(0.52 ; 0.79)^{*}$ & $1.30(1.17 ; 1.43)^{*}$ & $2.42(2.18 ; 2.65)^{*}$ \\
\hline \multicolumn{5}{|l|}{ Gender } \\
\hline Women (ref) & - & - & - & - \\
\hline Men & $0.22(0.15 ; 0.30)^{*}$ & $-0.16(-0.24 ;-0.07)^{*}$ & $0.21(0.12 ; 0.31)^{*}$ & $0.36(0.18 ; 0.55)^{*}$ \\
\hline Age & $-0.05(-0.05 ;-0.04)^{*}$ & $-0.03(-0.03 ;-0.02)^{*}$ & $-0.01(-0.02 ;-0.01)^{*}$ & $-0.05(-0.06 ;-0.04)^{*}$ \\
\hline \multicolumn{5}{|l|}{$\begin{array}{l}\text { Highest education level } \\
\text { completed }\end{array}$} \\
\hline $\begin{array}{l}\text { College/university/ } \\
\text { postgraduate (ref) }\end{array}$ & - & - & - & - \\
\hline High school & $-0.29(-0.40 ;-0.17)^{*}$ & $-0.09(-0.20 ; 0.02)$ & $-0.35(-0.47 ;-0.23)^{*}$ & $-0.64(-0.84 ;-0.44)^{*}$ \\
\hline Secondary school & $-0.44(-0.54 ;-0.33)^{*}$ & $-0.18(-0.32 ;-0.05)^{*}$ & $-0.55(-0.69 ;-0.42)^{*}$ & $-1.00(-1.22 ;-0.79)^{*}$ \\
\hline Primary school & $-0.66(-0.79 ;-0.52)^{*}$ & $-0.28(-0.43 ;-0.12)^{*}$ & $-0.60(-0.77 ;-0.43)^{*}$ & $-1.29(-1.62 ;-0.97)^{*}$ \\
\hline $\begin{array}{l}\text { Never/incomplete } \\
\text { primary school }\end{array}$ & $-0.95(-1.11 ;-0.79)^{*}$ & $-0.50(-0.65 ;-0.35)$ & $-0.64(-0.89 ;-0.40)^{*}$ & $-1.45(-1.82 ;-1.09)^{*}$ \\
\hline \multicolumn{5}{|l|}{ Occupation $(\text { ISCO } 08)^{\mathrm{b}}$} \\
\hline Skill level 1 (ref) & - & - & - & - \\
\hline Skill level 2 & $0.21(0.06 ; 0.36)^{*}$ & $0.05(-0.10 ; 0.19)$ & $0.28(0.11 ; 0.45)^{*}$ & $0.52(0.27 ; 0.78)^{*}$ \\
\hline Skill level 3 & $0.48(0.32 ; 0.64)^{*}$ & $0.21(0.05 ; 0.37)^{*}$ & $0.62(0.42 ; 0.82)^{*}$ & $1.21(0.90 ; 1.53)^{*}$ \\
\hline Never worked & $-0.38(-0.54 ;-0.22)^{*}$ & $-0.10(-0.26 ; 0.06)$ & $0.15(-0.07 ; 0.37)$ & $-0.01(-0.32 ; 0.31)$ \\
\hline \multicolumn{5}{|l|}{ Marital status } \\
\hline $\begin{array}{l}\text { Married or in } \\
\text { partnership (ref) }\end{array}$ & - & - & - & - \\
\hline Widowed & $-0.71(-0.81 ;-0.62)^{*}$ & $-0.46(-0.55 ;-0.36)^{*}$ & $-0.40(-0.51 ;-0.11)^{*}$ & $-1.30(-1.51 ;-1.08)^{*}$ \\
\hline Separated/divorced & $0.05(-0.09 ; 0.19)$ & $-0.19(-0.35 ;-0.02)^{*}$ & $-0.30(-0.47 ;-0.14)^{*}$ & $-0.76(-1.11 ;-0.40)^{*}$ \\
\hline Never married & $-0.01(-0.16 ; 0.13)$ & $-0.02(-0.14 ; 0.11)$ & $-0.31(-0.51 ;-0.11)^{*}$ & $-0.54(-0.90 ;-0.17)^{*}$ \\
\hline \multicolumn{5}{|l|}{ Urbanicity } \\
\hline Rural (ref) & - & - & - & - \\
\hline Urban & $0.18(0.00 ; 0.36)$ & $0.19(0.04 ; 0.34)^{*}$ & $0.17(-0.06 ; 0.41)$ & $0.30(-0.13 ; 0.73)$ \\
\hline
\end{tabular}

${ }^{a}$ Higher values indicate more AA.

${ }^{b}$ ISCO 08 categories were categorized into three levels according to their skill level. Skill level 3 corresponds to technicians and associate professionals, professionals, and managers. Skill level 2 corresponds to occupations between plant and machine operators and assemblers and clerical support workers. Skill level 1 corresponds to elementary occupations.

${ }^{*} p<0.05$

different welfare systems between socialdemocratic, southern, and eastern European countries (Eikemo et al., 2008).

When analyzing the different components of AA by country, Poland comes last in nearly every component. Poland has the highest percentage of disability, current smokers and sedentary lifestyle; and the lowest percentage of high cognition, social participation, social contacts, control, coping, and environmental safety. Finland, on the other hand has the best rates in most components. Although Spain is in a middle stage regarding AA components, it is worth highlighting the percentage of illiteracy and low education and occupation roles.
Whereas there is almost no illiteracy in the other two countries, almost one of every ten Spaniards aged 50 years and over is illiterate. More than three of ten did not complete primary school compared to less than $4 \%$ in Poland and less than $2 \%$ in Finland. This is especially important given the associations between education and occupation and AA. Growing old was associated with lower scores on all models of AA except for the psychosocial one. This is consistent with ten of ten longitudinal and three of five cross-sectional studies reviewed by Depp and Jeste (2006). The lack of associations with age in the psychosocial definition is consistent with the idea that the elderly can do as well or sometimes 
Table 5. Multiple linear regression showing associations [coefficient, $95 \%$ confidence interval $(95 \% \mathrm{Cl})$ ] with correlates on alternate AA models.

\begin{tabular}{|c|c|c|c|c|}
\hline & ROWE \& KAHN'S & BIOMEDICAL & PSYCHOSOCIAL & COMPLETE \\
\hline & RANGE (0-5) & RANGE $(0-7)$ & RANGE (0-6) & RANGE $(0-15)$ \\
\hline & $\begin{array}{l}\operatorname{MEAN}(3.0), 95 \% \mathrm{CI} \\
(2.9 ; 3.1)^{\mathrm{a}, \mathrm{b}}\end{array}$ & $\begin{array}{l}\text { MEAN }(4.7), 95 \% \mathrm{CI} \\
(4.6 ; 4.7)^{\mathrm{a}, \mathrm{b}}\end{array}$ & $\begin{array}{l}\text { MEAN (3.8), } 95 \% \mathrm{CI} \\
(3.6 ; 3.9)^{\mathrm{a}, \mathrm{b}}\end{array}$ & $\begin{array}{l}\text { MEAN }(9.5), 95 \% \mathrm{CI} \\
(9.3 ; 9.7)^{\mathrm{a}, \mathrm{b}}\end{array}$ \\
\hline & $\begin{array}{l}\text { COEFFICIENT } \\
(95 \% \mathrm{CI})\end{array}$ & $\begin{array}{l}\text { COEFFICIENT } \\
(95 \% \mathrm{CI})\end{array}$ & $\begin{array}{l}\text { COEFFICIENT } \\
(95 \% \mathrm{CI})\end{array}$ & $\begin{array}{l}\text { COEFFICIENT } \\
(95 \% \mathrm{CI})\end{array}$ \\
\hline \multicolumn{5}{|l|}{ Country } \\
\hline Poland (ref) & - & - & - & - \\
\hline Spain & $0.56(0.44 ; 0.68)^{*}$ & $0.45(0.31 ; 0.60)^{*}$ & $1.11(0.97 ; 1.25)^{*}$ & $1.78(1.51 ; 2.05)^{*}$ \\
\hline Finland & $0.91(0.82 ; 1.00)^{*}$ & $0.64(0.51 ; 0.78)^{*}$ & $1.26(1.13 ; 1.40)^{*}$ & $2.28(2.05 ; 2.51)^{*}$ \\
\hline \multicolumn{5}{|l|}{ Gender } \\
\hline Women (ref) & - & - & - & - \\
\hline Men & $0.08(0.01 ; 0.14)^{*}$ & $-0.28(-0.36 ;-0.21)^{*}$ & $0.07(-0.02 ; 0.16)$ & $0.00(-0.17 ; 0.16)$ \\
\hline Age & $-0.04(-0.04 ;-0.04)^{*}$ & $-0.02(-0.03 ;-0.02)^{*}$ & $-0.01(-0.01 ; 0.00)$ & $-0.03(-0.04 ;-0.03)^{*}$ \\
\hline \multicolumn{5}{|l|}{$\begin{array}{l}\text { Highest education level } \\
\text { completed }\end{array}$} \\
\hline $\begin{array}{l}\text { College/university/ } \\
\text { postgraduate (ref) }\end{array}$ & - & - & - & - \\
\hline High school & $-0.17(-0.28 ;-0.06)^{*}$ & $-0.02(-0.15 ; 0.11)$ & $-0.18(-0.30 ;-0.06)^{*}$ & $-0.33(-0.55 ;-0.10)^{*}$ \\
\hline Secondary school & $-0.19(-0.30 ;-0.08)^{*}$ & $0.00(-0.15 ; 0.16)$ & $-0.21(-0.38 ;-0.04)^{*}$ & $-0.37(-0.67 ;-0.07)^{*}$ \\
\hline Primary school & $-0.19(-0.33 ;-0.06)^{*}$ & $-0.02(-0.21 ; 0.17)$ & $-0.38(-0.56 ;-0.21)^{*}$ & $-0.63(-0.97 ;-0.28)^{*}$ \\
\hline $\begin{array}{l}\text { Never/incomplete primary } \\
\text { school }\end{array}$ & $-0.45(-0.60 ;-0.31)^{*}$ & $-0.28(-0.45 ;-0.10)^{*}$ & $-0.62(-0.89 ;-0.35)^{*}$ & $-1.05(-1.41 ;-0.69)^{*}$ \\
\hline \multicolumn{5}{|l|}{ Occupation (ISCO 08) ${ }^{\mathrm{c}}$} \\
\hline Skill level 1 (ref) & - & - & - & - \\
\hline Skill level 2 & $0.14(0.04 ; 0.25)^{*}$ & $0.07(-0.04 ; 0.17)$ & $0.21(0.06 ; 0.37)^{*}$ & $0.38(0.17 ; 0.60)^{*}$ \\
\hline Skill level 3 & $0.23(0.08 ; 0.37)^{*}$ & $0.12(-0.04 ; 0.29)$ & $0.41(0.21 ; 0.61)^{*}$ & $0.76(0.43 ; 1.08)^{*}$ \\
\hline Never worked & $-0.06(-0.20 ; 0.08)$ & $0.01(-0.13 ; 0.15)$ & $0.14(-0.03 ; 0.31)$ & $0.20(-0.04 ; 0.44)$ \\
\hline \multicolumn{5}{|l|}{ Marital status } \\
\hline $\begin{array}{l}\text { Married or in partnership } \\
\text { (ref) }\end{array}$ & - & - & - & - \\
\hline Widowed & $-0.13(0.24 ;-0.02)^{*}$ & $-0.25(-0.36 ;-0.14)^{*}$ & $-0.17(-0.28 ;-0.05)^{*}$ & $-0.60(-0.83 ;-0.38)^{*}$ \\
\hline Separated/divorced & $-0.15(-0.28 ;-0.02)^{*}$ & $-0.36(-0.54 ;-0.19)^{*}$ & $-0.46(-0.61 ;-0.30)^{*}$ & $-1.09(-1.44 ;-0.74)^{*}$ \\
\hline Never married & $-0.10(-0.23 ; 0.04)$ & $-0.10(-0.23 ; 0.03)^{*}$ & $-0.35(-0.52 ;-0.18)^{*}$ & $-0.67(-0.99 ;-0.34)^{*}$ \\
\hline \multicolumn{5}{|l|}{ Urbanicity } \\
\hline Rural (ref) & - & - & - & - \\
\hline Urban & $0.07(-0.02 ; 0.15)$ & $0.13(0.03 ; 0.23)^{*}$ & $-0.04(-0.16 ; 0.07)$ & $-0.03(-0.20 ; 0.15)$ \\
\hline Adjusted R-squared & 0.245 & 0.107 & 0.171 & 0.226 \\
\hline
\end{tabular}

a Adjusted for country, gender, age, education, occupation, marital status, and urbanicity.

${ }^{\mathrm{b}}$ Higher values indicate more AA.

' ISCO 08 categories were categorized into three levels according to their skill level. Skill level 3 corresponds to technicians and associate professionals, professionals, and managers. Skill level 2 corresponds to occupations between plant and machine operators and assemblers and clerical support workers. Skill level 1 corresponds to elementary occupations.

${ }^{*} p<0.05$

even better than young people regarding happiness or managing social relationships (Helmuth, 2003; Carstensen, 2006). There is also evidence that supports our finding that socioeconomic position was associated with AA (Strawbridge et al., 1996; Hank, 2011; Jeste et al., 2013). In our study, both education and occupation were independently associated with AA. Different mechanisms could be contributing to these associations. According to neo-material theories (Lynch, 2000), a lower socioeconomic position would be linked to having fewer resources to avoid risks, cure illnesses, prevent diseases, and living in a more deprived and unsafe environment. Behavioral theories (Kenkel, 1991) explain this phenomenon by means of an increase in cognitive skills or information through education that can enhance health behaviors and thus also prevent disease and increase quality of life. Finally, the psychosocial theories (Wilkinson, 2000) stress the idea of social comparison and the sense of lack of control on one's own life among those with a lower position. Being currently married 
Table 6. Multiple linear regression showing associations with the complete model of AA [coefficient, $95 \%$ confidence interval $(95 \% \mathrm{Cl})]$ by country.

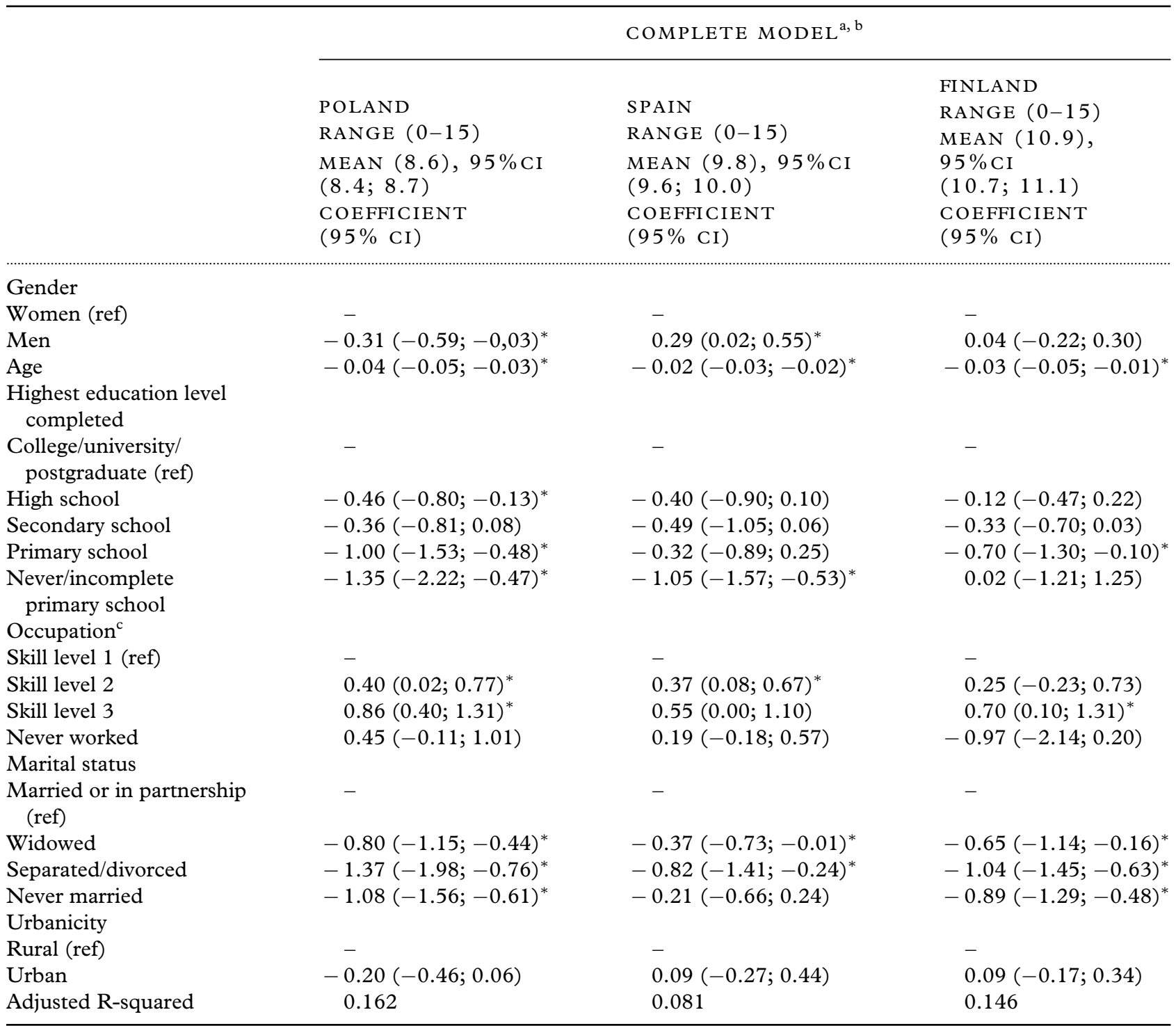

${ }^{a}$ Adjusted for gender, age, education, occupation, marital status, and urbanicity.

${ }^{\mathrm{b}}$ Higher values indicate more AA.

cISCO 08 categories were categorized into three levels according to their skill level. Skill level 3 corresponds to technicians and associate professionals, professionals, and managers. Skill level 2 corresponds to occupations between plant and machine operators and assemblers and clerical support workers. Skill level 1 corresponds to elementary occupations. ${ }^{*} p<0.05$

or cohabiting was associated to higher AA scores compared to being widowed, divorced, or even never married in different definitions of AA. Only one of seven longitudinal studies and none out of three cross-sectional studies found current marriage to be associated with AA in a recent systematic review (Depp and Jeste, 2006). The associations with marital status could be related to social support mechanisms given that one of the primary benefits of marriage is social connectedness or more instrumental aspects of marriage such as finances.

\section{Limitations}

There are a number of limitations to this descriptive study. First, different models of AA have been employed, showing sometimes discordant results. This highlights the need for an improved agreement on the definition of $\mathrm{AA}$ and the corresponding measurement approaches. However, models are simplified representations of reality and there is no true model of AA. Researchers and interested professionals need to select definitions and models that are contextually appropriate and robust. Our assessment of AA gives the same weight to the 
different variables included in the definition, which may not be adequate in some cases. This study has a cross-sectional design and therefore, causality cannot be inferred from the associations. Because of this type of design, it is impossible to disentangle age from cohort effects. Institutionalized people are not part of the target population; these people are more likely to have worse health outcomes. Unhealthy older women have a greater probability of living in residential settings since women have higher life expectancy than men and therefore might be underrepresented. People with lower socioeconomic position might have higher mortality (Berkman and Kawachi, 2000). This may lead to survival bias. Since the present study was not part of the main aims of the COURAGE in Europe project, we did not include all aspects of AA (i.e. environmental fit, personal growth, etc.). However, we have included a number of variables that are representative of the major components of AA, namely biomedical, psychosocial, and external factors.

\section{Implications}

These findings have interesting implications for public health policies. There are numerous aspects in which the three countries could promote AA. This can be achieved by reducing inequalities in education and occupation in these three countries since they have been consistently associated with AA. Alternatively, measures can be taken to increase AA by improving individual components of AA directly. Poland, for example, should focus on tackling components of AA such as disability given that the prevalence of disability in this country is high compared to Spain and Finland. According to the WHO International Classification of Functioning Disability and Health (ICF) (World Health Organization, 2001), in order to decrease disability, interventions should be aimed at the environment and not only focusing on the individual's functioning (World Health Organization, 2001). In the case of Spain, special emphasis should be put on education and reducing gender differences. Even though education in Spain is now compulsory until age 16 , cuts are currently being implemented in education to the extent that the budget for education has decreased to $31.6 \%$ from 2011 to 2013 (Presupuestos Generales del Estado, 2011; 2013). Also tuition fees are being increased in universities due to the crisis (Diari Oficial de la Comunitat Valenciana, 2011; 2012). This is a threat to AA for future generations given the consistent education gradients across all definitions of AA. Gender inequalities have been found specifically for Spain. Despite being the country with more active agers, Finland can still benefit from tackling social inequalities. Chronic conditions, alcohol consumption, and social support are areas in which Finland could focus their efforts. Further, studies should focus on aspects related to support in people who are not married or cohabiting and the association with AA. These people show lower levels of AA in the three countries. The associations found may vary depending on the gender of the individual. Future research will be necessary to shed light on this issue.

\section{Conclusions}

Active aging will play an important role in improving the health of populations across Europe in the context of a continued growth of older age groups. Multidimensional models that include psychosocial, biomedical, and external factors and follow a continuum in which people can score higher or lower in AA will best help detect areas of deficiency and proficiency and thus suggest ways to identify good or bad praxis in interventions aimed at AA. This will help understanding and promoting AA in different populations.

\section{Conflict of interest}

None.

\section{Description of author' roles}

The study design was planned by JP, JA, SC, SK, $\mathrm{ML}, \mathrm{MM}, \mathrm{BT}, \mathrm{BO}$, and JH. JP conducted the data analyses. JP and SM drafted the article. JH supervised the data analyses and development of the paper. The paper was edited and reviewed by all the authors.

\section{Acknowledgments}

The research leading to these results has received funding from the European Community's Seventh Framework Programme (FP7/2007-2013) under grant agreement number 223071 (COURAGE in Europe), from the Instituto de Salud Carlos III-FIS research grant number PS09/01845 and PS09/00295 and from the Spanish Ministry of Science and Innovation ACI-Promociona (ACI2009-1010). The study was supported by the Centro de Investigación Biomédica Red de Salud Mental (CIBERSAM), Instituto de Salud Carlos III, and Recercaixa 2011. J.P. is grateful to the Instituto de Salud Carlos III for a predoctoral grant (PFIS). J.P. is grateful to Mendeley reference 
manager for providing an open source tool for reference editing.

\section{Abbreviations}

AA: active aging, EU European Union, WHO: World Health Organization, WHODAS II: World Health Organization Disability Schedule version II, CIDI: Composite International Diagnostic Interview, ISCO-08: International Standard Classification of Occupations (08).

\section{References}

Armstrong, T. and Bull, F. (2006). Development of the World Health Organization Global Physical Activity Questionnaire (GPAQ). Fournal of Public Health, 14, 66-70.

Berkman, L. F. and Kawachi, I. (2000). Social Epidemiology, Social Science. Oxford: Oxford University Press.

Bøen, H., Dalgard, O. S. and Bjertness, E. (2012). The importance of social support in the associations between psychological distress and somatic health problems and socio-economic factors among older adults living at home: a cross sectional study. BMC Geriatrics, 12, 27.

Bowling, A. (1993). The concepts of successful and positive ageing. Family Practice, 10, 449-453.

Bowling, A. and Dieppe, P. (2005). What is successful ageing and who should define it? BMF, 331, 24-31.

Bowling, A. and Iliffe, S. (2006). Which model of successful ageing should be used? Baseline findings from a British longitudinal survey of ageing. Age and Ageing, 35, 607-14.

Carstensen, L. L. (2006). The influence of a sense of time on human development. Science, 312, 1913-1915.

Cosco, T. D., Prina, A. M., Perales, J., Stephan, B. C. M. and Brayne, C. (2013). Lay perspectives of successful ageing: a systematic review and meta-ethnography. BMF Open, 3, e002710.

Depp, C. A. and Jeste, D. V. (2006). Definitions and predictors of successful aging: a comprehensive review of larger quantitative studies. American fournal of Geriatric Psychiatry, 14, 6-20.

Diari Oficial de la Comunitat Valenciana. (2011). Decret 104/2011. Available at: http://sga.ua.es/es/documentos/ normativa-academica/tasas/decreto-de-tasas-2010-2011.pdf; last accessed 21 March 2014.

Diari Oficial de la Comunitat Valenciana. (2012). Decret 110/2012. Available at: http://www.docv.gva.es/datos/ 2012/07/09/pdf/2012_6859.pdf; last accessed 21 March 2014.

Eikemo, T. a, Huisman, M., Bambra, C. and Kunst, A. E. (2008). Health inequalities according to educational level in different welfare regimes: a comparison of 23 European countries. Sociology of Health and Illness, 30, 565-582.

European Commission. (2009). Commission recommendation of 29 October 2009 on the use of the International Standard Classification of Occupations (ISCO-08). Official fournal of the Eurean Union, 292, 31-47.
European Union. (2012). European Year for Active Ageing and Solidarity between Generations. [WWW Document]. Available at: http://europa.eu/ey2012/ey2012main. jsp?catId=971\&langId=en; last accessed 9 March 2013.

Fernández-Ballesteros, R. (2008). Lay concept of aging well: Cross-cultural comparisons. Fournal of the American Geriatrics Society, 56, 950-952.

Fernández-Ballesteros, R., Molina-Martínez, M. A., Schettini-del-Moral, R. and Santacreu, M. (2013). The semantic network of aging well. In J. M. Robine, C. Jagger and E. Crimmins (eds.), Annual Review of Gerontology and Geriatrics: Healthy Longevity. (pp. 79-107). New York: Springer.

Fries, J. F. (2012). The theory and practice of active aging. Current Gerontoly and Geriatrics Research, 2012 , 420637.

Hank, K. (2011). How "successful" do older Europeans age? Findings from SHARE. Fournal of Gerontology: Social Sciences, 66B, 230-236.

He, W., Muenchrath, M. N. and Kowal, P. (2012). Shades of Gray: A Cross-Country Study of Health and Well-Being of the Older Populations in SAGE Countries, 2007-2010. Washington, DC: US Census Bureau.

Helmuth, L. (2003). The wisdom of the wizened. Science, 299, 1300-1302.

Ibrahim, F., Cohen, C. and Ramirez, P. (2010). Successful aging in older adults with schizophrenia: prevalence and associated factors. American fournal of Geriatric Psychiatry, 18, 879-886.

Jeste, D. V. et al. (2013). Association between older age and more successful aging: critical role of resilience and depression. American fournal of Psychiatry, 170, 188196.

Kenkel, D. S. (1991). Health behavior, health knowledge, and schooling. Fournal of Political Economy, 99, 287-305

Kerschner, H. and Pegues, J. A. (1998). Productive aging: a quality of life agenda. Fournal of the American Dietetic Association, 98, 1445-1448.

Kessler, R. C. and Ustün, T. B. (2004). The World Mental Health (WMH) survey initiative version of the World Health Organization (WHO) Composite International Diagnostic Interview (CIDI). International fournal of Methods in Psychiatric Research, 13, 93-121.

Lupien, S. J. and Wan, N. (2004). Successful ageing: from cell to self. Philosophical transactions of the Royal Society of London. Series B, Biological Sciences, 359, 1413-1426.

Lynch, J. (2000). Income inequality and health: expanding the debate. Social Science \& Medicine, 51, 1001-1005.

Malaspina, L. et al. (2011). Successful cognitive aging in persons living with HIV infection. Fournal of Neurovirology, 17, 110-119.

Presupuestos Generales del Estado. (2011). Ley 39/2010. Available at: https://www.boe.es/diario_boe/txt.php?id= BOE-A-2010-19703; last accessed 21 March 2014.

Presupuestos Generales del Estado. (2013). Ley 17/2012. Available at: http://www.boe.es/buscar/pdf/2012/ BOE-A-2012-15651-consolidado.pdf; last accessed 21 March 2014.

Rowe, J. W. and Kahn, R. L. (1997). Successful aging. Gerontologist, 37, 433-440.

StataCorp. (2009). Stata: Release 11. Stata Software. Available at: http://www.stata.com/stata11/; last accessed 21 March 2014. 
Strawbridge, W. J., Cohen, R. D., Shema, S. J. and Kaplan, G. A. (1996). Successful aging: predictors and associated activities. American fournal of Epidemiology, 144, 135-141.

Ustun, T., Chatterji, S., Mechbal, A., Murray, C. and WHS Collaborating Groups. (2005). Quality assurance in surveys: standards, guidelines and procedures. In Department of Economic and Social Affairs Statistics Division of the United Nations (ed.). Household Sample Surveys in Developing and Transition Countries. New York: United Nations.

Walker, A. (2009). Commentary: the emergence and application of active aging in Europe. Fournal of Aging $\mathcal{E}$ Social Policy, 21, 75-93.

Wilkinson, R. G. (2000). Inequality and the social environment: a reply to Lynch et al. Fournal of Epidemiology and Community Health 54, 411-3.

World Health Organization. (1990). World Health Annual Statistics. Geneva: World health Organization.
World Health Organization. (1992). ICD-10 Classification of mental and behavioural disorders. Geneva: World health Organization.

World Health Organization. (2001). International Classification of Functioning, Disability and Health (ICF). Geneva: World health Organization.

World Health Organization. (2012). The World Health Organization Disability Assessment Schedule II (WHODAS

II) [WWW Document]. http://www.who.int/icidh/whodas/ index.html; last accessed 15 March 2013.

World Health Organization. (2013a). Ageing and life course: What is "active ageing" [WWW Document].

http://www.who.int/ageing/active_ageing/en/; last accessed 15 March 2013.

World Health Organization. (2013b). World Health Organization Translation Guidelines [WWW Document]. http://www.who.int/substance_abuse/ research_tools/translation/en/; last accessed $15 \mathrm{March}$ 2013. 